\title{
VEGETATION STRUCTURE, NATURAL REGENERATION AND MANAGEMENT OF PARROHA COMMUNITY FOREST IN RUPANDEHI DISTRICT, NEPAL
}

\author{
Rajendra Acharya* and Bharat Babu Shrestha** \\ *Xavier International College, Kathmandu, Nepal. \\ **Central Department of Botany, Tribhuvan University, Kirtipur, Kathmandu, Nepal.
}

\begin{abstract}
Understanding vegetation structure and regeneration in community forests in important for management planning. The present work was done during September to October 2005. The information on forest management practices was collected by Participatory Rural Appraisal (PRA) which included field observation, interviews and focus group discussion. A total of 125 plant species belonging to 55 families with 36 tree species, 50 shrubs and 39 herbs were recorded from the 0.7 ha sampling area. The total tree density and basal area at South-East (SE) facing slope was $595 \mathrm{pl} / \mathrm{ha}$ and $29.68 \mathrm{~m} / \mathrm{ha}$, respectively, where Terminalia alata was the most dominant with highest importance value index (IVI). On the other hand, total tree density and basal area was $453 \mathrm{pl} / \mathrm{ha}$ and $41.78 \mathrm{~m}^{2} / \mathrm{ha}$, respectively, at South-West (SW) facing slope, where Shorea robusta was the most dominant with the highest IVI. Total shrub/sapling density was $4708 \mathrm{pl} /$ ha at SE slope and $4137 \mathrm{pl} / \mathrm{ha}$ at SW slope. Similarly, total herb/seedling density was $10.86 \mathrm{pl} / \mathrm{m}^{2}$ at SE slope and $9.79 \mathrm{pl} / \mathrm{m}^{2}$ at SW slope. The total number of tree species (S) in tree stage was higher at SE slope than at SW slope and the number of species in shrub layer was higher at SE slope than at SW slope. The two slopes had nearly equal number of species in herbaceous layer. Higher species diversity $(\mathrm{H})$ of different lifeforms was found at SW slope. The SW slope had higher species evenness (J) and Simpson's index of dominance (C) for all life forms than at SE slope. High similarity index for all tree, shrub/sapling and herb/seedling layers (63.63\%, 84.61\% and $77.10 \%$ respectively) were found between two sites. Alpha $(\alpha)$ diversity for shrub layer was higher at SE slope whereas beta ( $\beta$ ) diversity for tree layer was higher at SW slope than at SE slope. Regeneration of Shorea robusta and Terminalia alata was continuous because density increased from tree, sapling to seedlings with a typical reverse J shaped size class diagram at both slope. But regeneration of S. robusta at SW slope was sporadic. The reccurence of forest fire during summer season has appeared as a major problem for the management of forest. The active participation of the local people in forest conservation activities can be effective for sustainable management of forest.
\end{abstract}

Keywords: Community forestry; Vegetation; Regeneration; Size class diagram; Shorea robusta; Terminalia alata.

\section{INTRODUCTION}

Presently dense tropical forests in Terai region has been destroyed due to population growth, migration of people from hills to Terai and encroachment of forest area for settlement and cultivated land. The pressure on forest is increasing with the growing demand for forest products and for various commercial activities. In Nepal, forests provide about $42 \%$ of fodder supply to livestock and it is predicted that there will a deficit in the available total digestible nutrients (TDNs) by the year 2010 (MoPE, 2004). It plays a major role (80\%) in the energy supply of Nepal and its consumption is increasing by $2.0 \%$ per annum (Shrestha, 2000). Community forestry is a major forest management program implemented by the government of Nepal and is regarded as the most successful (NPC 2001, NIghtiang 2002, Acharya 2003) in forest and biodiversity conservation. It has now become an integral part for managing natural resources through the active involvement of local people (GoN, 2007). In Nepal, giving right of management of forest to user groups can be a more viable way than any other types of management in forestry (Metz, 1991). Community forest management invariably leads to reduced level of grazing within the forest, reduced incidence of fire and of wildlife poaching (Sigdel, 2004); these are likely to lead to increased biodiversity. It has been well documented that after the initiation of CF programme, most of the handed over forest have been well protected and managed properly leading to a significant improvement in the condition of the forests (GoN, 2007). Natural regeneration is the process of regrowing or reproduction of plants through their juvenile. It

Author for Correspondence: Bharat Babu Shrestha, Central Department of Botany, Tribhuvan University, Kirtipur, Kathmandu, Nepal. Email: bb.shrestha@cdbtu.edu.np 
is important not only for the reproductive role but also for ensuring the replacement of any member of a community that dies off after completing life cycle (Fatubarin, 1987). Population structure of a species in a forest can convey its regeneration behavior particularly the reproductive strategy (Singh and Singh, 1992). Population structure characterized by the presence of sufficient population of seedlings, saplings and young trees indicate a successful regeneration of forest species (Saxena and Singh, 1984).

Regeneration pattern determines the species composition and stability in the future. Although natural regeneration is very slow process, it is important process to maintain the stable age structure in the species of plant in a community). Undisturbed old growth forests with sustainable regeneration found to have a reverse $\mathrm{J}$ shaped size class distribution is the characteristic (West et al., 1981). A bell shaped size class distribution has been attributed to disturbed forest, where regeneration is hampered (Saxena et al., 1984). The systematic documentation of biological resources and their status may help in the sustainable management of community forest. Therefore we conducted present ecological research: (i) to document the quantitative community characters of the forest. (ii) to study the natural regeneration of dominant and co-dominant species and (iii) assess the existing forest management practices

\section{MATERIALS AND METHODS}

\section{Study Area}

Parroha VDC is located in Rupandehi district which lies between $27^{\circ} 20^{\prime}$ to $27^{\circ} 45^{\prime} \mathrm{N}$ latitude, $83^{\circ} 10^{\prime}$ to $83^{\circ} 30^{\prime}$ E longitude. It is a part of terai region of Nepal and covers a total area of 73196.1 hectare sq. of which about $73 \%$ is agricultural land, urban areas and roads, 23\% forest and remaining 4\% water resources (Anonymous, 2007). Present research was conducted in Parroh communiry forest of Parroh VDC with an area of 633ha with 1267 households (HH) and 8849 members are involved as forest user groups (FUGs). Majority of study area comprises south facing slope with several micro aspect ranging from South-East to South- West. Two sites (SE slope: South-East facing slope and SW slope: South-West facing slope) lying between 250 and $550 \mathrm{~m}$ asl were selected for the present study. Ghamaha khola, a perennial river, passes through mid of two slopes. For management purposes the Parroha Community Forest has been divided into three blocks. Present study was carried out mainly in Rani block (SE slope) and Kapase block (SW slope) of PCF separated by a Ghamaha Khola. The forest is mainly dominated by hill sal (Shorea robusta) forest with sal as a dominant tree species. Other associated species are Saj (Terminalia alata), Banjhi (Anogeissus latifolia), Pyari (Buchanania latifolia). The climate of the study area is typically tropical, dominated by South east monsoon. A hot climate generally prevails throughout the years except in the short winter. The temperature ranges from an average of $7^{\circ} \mathrm{Cin}$ winter to an average of $45^{\circ} \mathrm{C}$ in summer. The soil was sandy loam and acidic in nature.

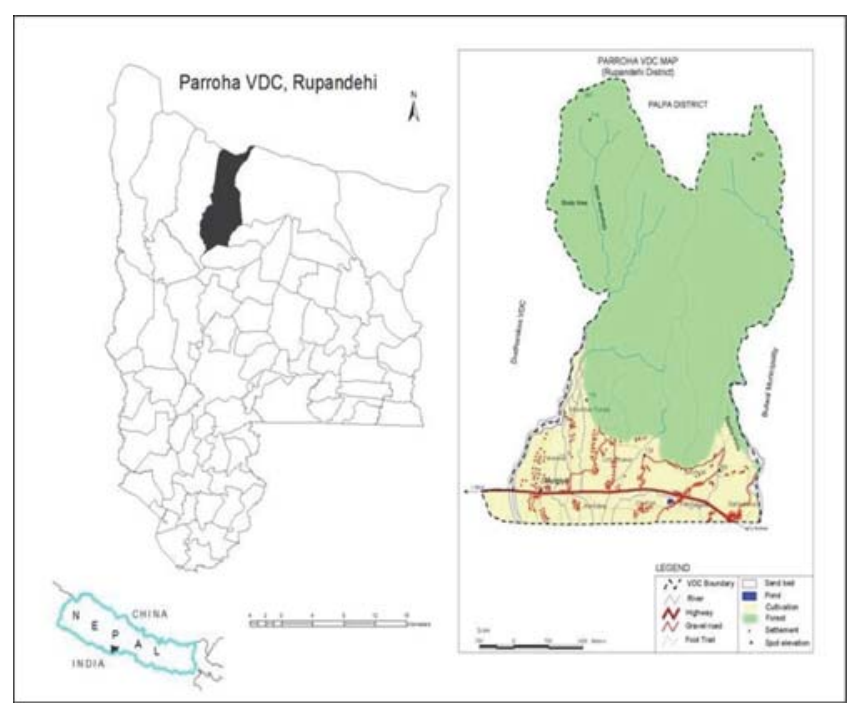

Figure 1: map of the study area

\section{Forest Sampling}

In view of the heterogenous landscape, we choose to use relatively small quadrats of $10 \mathrm{~m} \times 10 \mathrm{~m}$. In each site three parallel transects were visually defined from 250 to $550 \mathrm{~m}$ asl. Each transect was divided into four elevation bands at the interval of $100 \mathrm{~m}$ elevation increment. In each elevation band of each transect three quadrats $(10 \mathrm{~m} \times 10 \mathrm{~m})$ were sampled for trees. Among these three quadrats one lied along the transect line and two on either sides at a distance of 40 to 100 $\mathrm{m}$. Therefore altogether 36 quadrats were sampled for trees in each site, with twelve quadrates in each elevation band. In each quadrat, individual trees (diameter at breast height (dbh) e” $10 \mathrm{~cm}$ ) of each species were counted and dbh of each individual was measured. Canopy cover of each plot was estimated by visual estimation from the centre of each plot. Each quadrat for trees was divided into four quarters $(5 \mathrm{~m} \times 5$ $m$ each) and two of them lying diagonally were randomly selected for sampling shrub layer (sapling $(\mathrm{dbh}<10 \mathrm{~cm}$ and $>2.5 \mathrm{~cm}$ and height $>30 \mathrm{~cm}$ ) and shrub species) (Sundriyal and Sharma, 1996). Number of individuals of each species of shrubs and saplings within the quadrate were recorded and canopy cover of each species of shrubs and saplings was visually estimated. A sub-quadrat $(1 \mathrm{~m} \times 1 \mathrm{~m})$ was sampled for herbs and seedlings (dbh 0 , height $<30 \mathrm{~cm}$ ) were laid down in four corners of the $10 \mathrm{~m} \times 10$. In each sub-quadrat number of individuals and coverage of each species of herbs and seedling were recorded. Therefore the number of sampling plots for tree was 36, for shrub 72 and that for herbs was 144 at each site. We identified plants $10 \mathrm{~m} \times 10 \mathrm{~m}$ with the help of standard references (Stainton, 1997 and Polunin \& Stainton, 20000) and with cross checking the specimens deposited at Tribhuvan University Central Herbarium (TUCH), Kirtipur.We calculated density $\left(\mathrm{ha}^{-1}\right)$, frequency (\%), (basal area $\left(\mathrm{m}^{2} \cdot \mathrm{ha}^{-1}\right)$ (of trees), coverage (\%) (of herb, seedlings \& saplings), as well as their relative values and importance value index (IVI) following Zobel et al. (1987). Tree density and dbh classes (10-20, 20-30, 30-40 cm, etc.) of Shorea robusta and Terminalia alata were used to develop a size class distribution diagram. Simpson's index of dominance (C) was calculated following 
Table 1: Number of species (S), Species Evenness (J), Simpson’s Index of Dominance (C) and Shannon-Weiner Index of species Diversity (H) for tree, shrub/sapling and herbs/seedling layer.

\begin{tabular}{|c|c|c|c|c|c|c|c|c|c|c|c|c|}
\hline \multirow[b]{2}{*}{ Slope } & \multicolumn{3}{|c|}{$\mathrm{S}$} & \multicolumn{3}{|c|}{$\mathrm{J}$} & \multicolumn{3}{|c|}{$\mathrm{C}$} & \multicolumn{3}{|c|}{$\mathrm{H}$} \\
\hline & $\begin{array}{c}\text { Tree } \\
\text { Layer }\end{array}$ & $\begin{array}{l}\text { Shrub } \\
\text { Layer }\end{array}$ & $\begin{array}{l}\text { Herb } \\
\text { Layer }\end{array}$ & $\begin{array}{c}\text { Tree } \\
\text { Layer }\end{array}$ & $\begin{array}{l}\text { Shrub } \\
\text { Layer }\end{array}$ & $\begin{array}{l}\text { Herb } \\
\text { Layer }\end{array}$ & $\begin{array}{c}\text { Tree } \\
\text { Layer }\end{array}$ & $\begin{array}{l}\text { Shrub } \\
\text { Layer }\end{array}$ & $\begin{array}{l}\text { Herb } \\
\text { Layer }\end{array}$ & $\begin{array}{c}\text { Tree } \\
\text { Layer }\end{array}$ & $\begin{array}{l}\text { Shrub } \\
\text { Layer }\end{array}$ & $\begin{array}{l}\text { Herb } \\
\text { Layer }\end{array}$ \\
\hline SE & 23 & 66 & 42 & 0.65 & 0.64 & 0.60 & 0.20 & 0.10 & 0.14 & 2.04 & 2.71 & 2.27 \\
\hline SW & 21 & 64 & 41 & 0.68 & 0.69 & 0.66 & 0.19 & 0.07 & 0.12 & 2.10 & 2.89 & 2.48 \\
\hline
\end{tabular}

Table 2: á and â diversity of Tree, Shrub and Herb layers at two sites

\begin{tabular}{|c|c|c|c|c|c|c|}
\hline \multirow[b]{2}{*}{ Slope } & \multicolumn{3}{|c|}{$\alpha$ diversity } & \multicolumn{3}{|c|}{$\beta$ diversity } \\
\hline & $\begin{array}{l}\text { Tree Layer } \\
\mathrm{sp} / 100 \mathrm{~m}^{2}\end{array}$ & $\begin{array}{c}\text { Shrub Layer } \\
\mathrm{sp} / 25 \mathrm{~m}^{2}\end{array}$ & $\begin{array}{c}\text { Herb Layer } \\
\mathrm{sp} / \mathrm{m}^{2}\end{array}$ & Tree Layer & Shrub Layer & Herb Layer \\
\hline SE & 3.25 & 6.09 & 4.08 & 2.19 & 1.83 & 1.66 \\
\hline SW & 3.13 & 5.91 & 3.89 & 2.10 & 1.88 & 1.50 \\
\hline
\end{tabular}

Simpson (1949) and diversity index $(\mathrm{H})$ was calculated following Magurran (2004). Similarly species evenness (J) following Magurran (2004), alpha (á) and beta (â) diversity was calculated following Whittaker (1972). We collectrd field data during September to October 2005. The information on forest management was based on Participatory Rural Appraisal (PRA) method. PRA and informal interviews were conducted with the members of committee of PCF and with (FUGs) of sampled household $(\mathrm{HH})$. We predicted the relation between seedling density of sal (Shorea robusta) and saj (Terminalia alata) with tree canopy cover by the linear regression equation.

\section{RESULT}

\section{Forest Structure}

Altogether 36 tree species, 50 shrub species including climber and 39 herb species including herbaceous climber, grasses and pteridophytes were recorded from SE and SW slopes. Shorea robusta (178 pl/ha) was the most densely populated tree at SE slope followed by Terminalia alata (150 pl/ha), Anogeissus latifolia (61 pl/ha), Lagerstroemia parviflora (39 $\mathrm{pl} / \mathrm{ha}$ ), etc (Annex 1). At SW slope, Shorea robusta (172 pl/ ha) was the most densely populated tree species followed by Terminalia alata (86 pl/ha), Anogeissus latifolia (36 pl/ha), Semecarpus anacardium (31 pl/ha), Buchanania latifolia (28 pl/ha), etc.(Annex 2) . Similarly, basal area (BA) was the highest for Terminalia alata $\left(11.72 \mathrm{~m}^{2} / \mathrm{ha}\right)$ at SE slope and for Shorea robusta (26.47 m²/ha) at SW slope (Annex 1 \& 2). Based on IVI Terminalia alata (93.12) was the most dominant tree species at SE slope and Shorea robusta (127.20) at SW slope. (Annex 1\& 2). Among the shrub species at SE slope, Phoenix humilis had the highest density (544 pl/ha) followed by Barleria strigosa (422 pl/ha), Millettia extensa (311 pl/ ha), Leea macrophylla (239 pl/ha), etc.(Annex 3) Similarly, at SW slope Phoenix humilis had the highest density (517 pl/ ha) followed by Millettia extensa (411 pl/ha), Leea indica (278 pl/ha), Barleria strigosa (256 pl/ha), etc. (Annex 4). Density of sapling of Shorea robusta (1228 pl/ha) was the highest among the shrubs (including saplings of trees) at SE slope, followed by Terminalia alata (369 pl/ha), Lagerstroemia parviflora (72 pl/ha), etc. (Annex 3). Similarly at SW slope also, saplings of Shorea robusta had the highest density (744 pl/ha) followed by Terminalia alata (267 pl/ha), Buchanania latifolia (100 pl/ha), etc. (Annex 4). Among the herbs Carex cruciata was the dominant species with highest IVI at both sites (Annex 5 \& 6) Among the seedlings of tree species, the highest IVI was contributed by seedlings of Shorea robusta at both slopes followed by Terminalia alata (Annex 5 \& 6).

\section{Species number, diversity and regeneration}

The total number of tree species (S) in tree layer was higher at SE slope than at SW slope and the number of species in shrub layer was higher at SE slope than at SW slope. The two slopes had nearly equal number of species in herbaceous layer. The SW slope had higher species evenness (J) and Simpson's Index of dominance (C) than SE slope ShannonWeiner Index of species diversity $(\mathrm{H})$ was higher at SW slope than SE slope for all life forms (Table 1).

Alpha (á) diversity was higher at SE slope than at SW slope for all life forms (Table 2). Beta (â) diversities of the two sites were nearly equal for shrub layer but for herbs and tree layer, it was higher for SE slope.

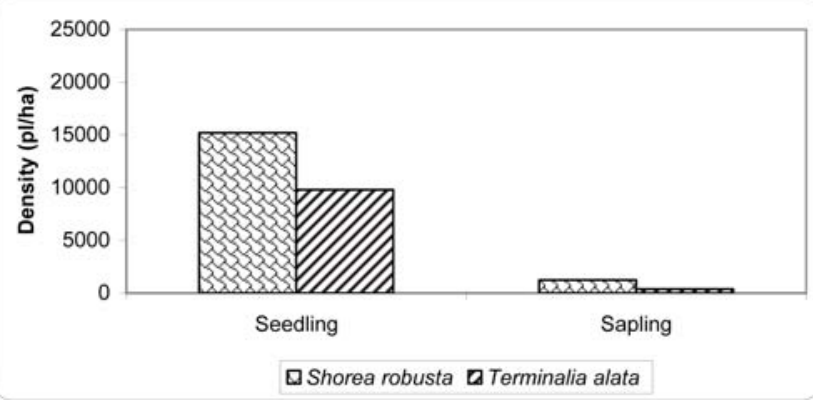

Figure 2: Seedling and Sapling density of Shorea robusta and Terminalia alata at SE slope

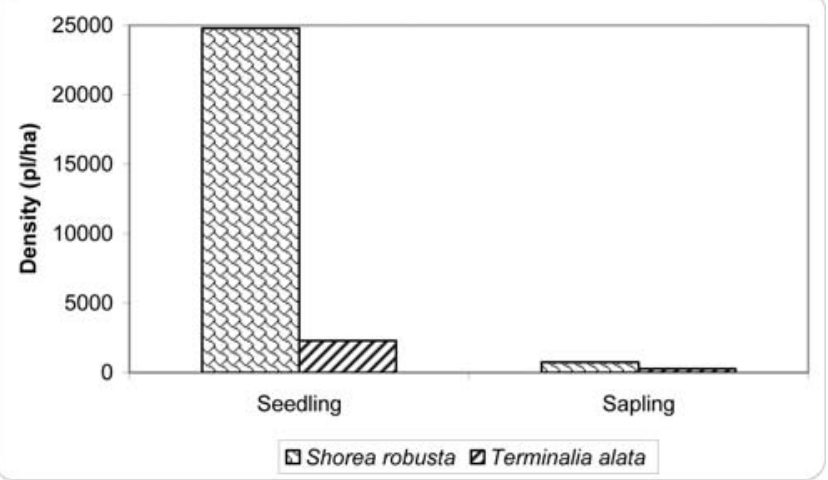

Figure 3: Seedling and Sapling density of Shorea robusta and Terminalia alata at SW slope 
The regeneration potential of Shorearobusta was higher than that of Terminalia alata as indicated by seedling and sapling density of S. robusta i.e. 15208 and $1228 \mathrm{pl} /$ ha respectively at SE slope whereas 24792 and $744 \mathrm{pl} / \mathrm{ha}$ at SW slope respectively (Figure $2 \& 3$ )

Shorea robusta and Terminalia alata were fairly high regenerating with a typical reverse J- shaped size class distribution (except Shorea robusta at SW slope ) (Figure 4,5,6 \& 7). The bell - shaped size class distribution curve of $S$. robusta at SW slope (Figure 7) showed the regeneration of $S$. robusta was sporadic . However, regeneration of Anogeissus latifolia was found to be very low i.e. no seedling and very few saplings under adult trees.

Above linear regression analysis showed contrasting behavior of Shorea robusta and Terminalia alata seedling. Seedling density of $S$. robusta declined with the increasing tree canopy cover. However, the relation between seedling density of S. robusta and tree canopy cover was not significant. Seedling density of T. alata increased with increasing tree canopy cover.

\section{Forest Management}

In January 2003, the forest was officially handed over to the CFUGs as community forest. Based on natural boundaries, the forest has been divided into three blocks and the management plan harvesting operation has been developed on a five year rotational basis. The forest has been opened three times a year at the interval of four months for the collection of fuel wood. People can cut dead tree/shrub and fallen branches (but not live individuals) for firewood, however, some stumps and lopped of branches of trees were observed during the field sampling. After taking permission and paying some royalties according to rules of FUGs committee, member of FUGs can extract wood for agricultural equipments (like plough, juwa, sickle, paddle etc.) and thatching material like Eulaliopsis binnata for making rope. The collection of fodder and rooting material from the forest is allowed twice a week throughout the year. A large proportion of fodder had been derived from the forest before the inception of community management. FUGs committee generally prefer to harvest timber from Shorea robusta and Terminalia alata and firewood of any kind of tree and shrub species annually after taking permission from DFO and sell to the members of comsumer groups, which is the main source of income generation of CFUG. They were harvested $676 \mathrm{cu}$. $\mathrm{ft}$. timber and 215 quintle firewood in the year 2004/005.The collected income that they spend for the welfare of society and managemwent of forest as well. There are some medicinally valuable plants like Cassia fistula, Semecarpus anacsardium, Curculigo orchioides, etc. As fodder, villagers generally use grasses (herbaceous fodder plants) and tree fodder like Shorea robusta, Terminalia alata, Bridelia retusa, Bauhinia purpurea, Ficus racemusa, Desmodium oojeinense, Schleichera oleosa, Holarhena pubescens, Woodfordia fruticosa, Premna integrifolia etc. S. robusta, T. alata and Banjhi (Anogeissus latifolia) were preferred tree for fodder, but use of these species as fodder was restricted after the

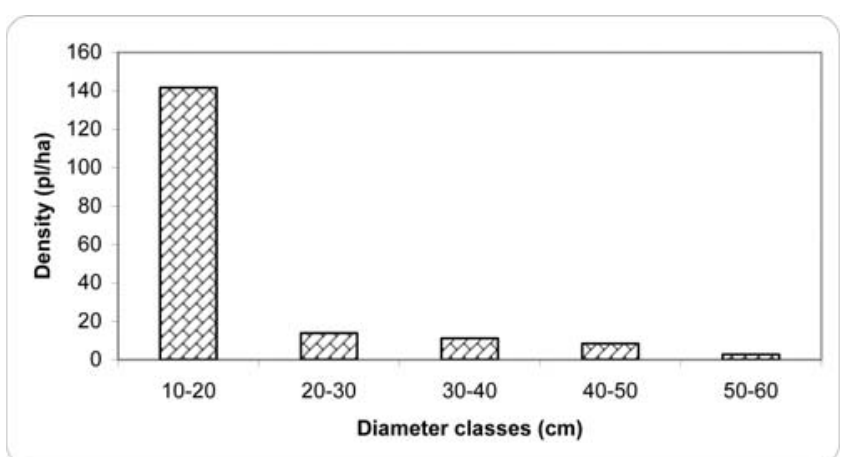

Figure 4: Density of different diameter classes of trees of Shorea robusta at SE slope

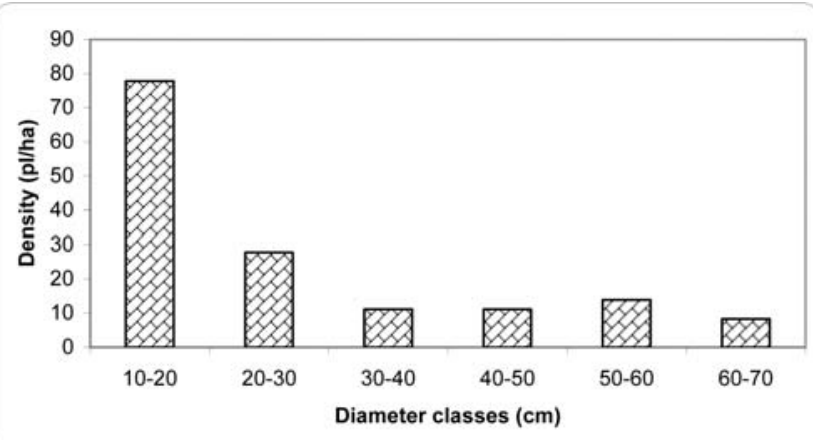

Figure 5: Density of different diameter classes of trees of Terminalia alata at SE slope

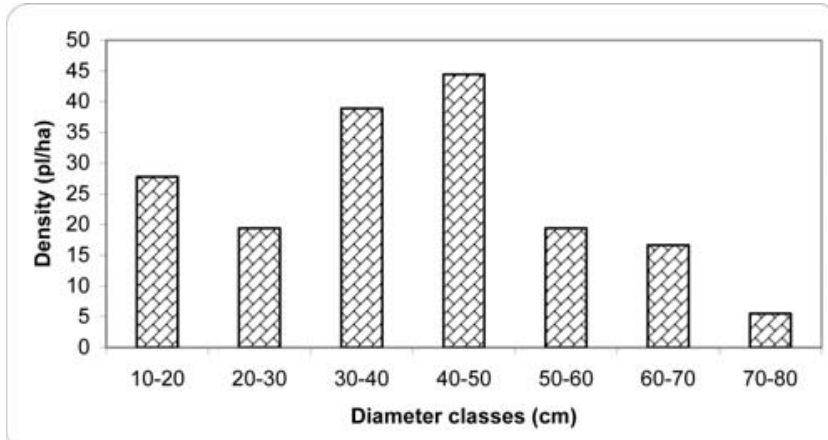

Figure 6: Density of different diameter classes of trees of Shorea robusta at SW slope

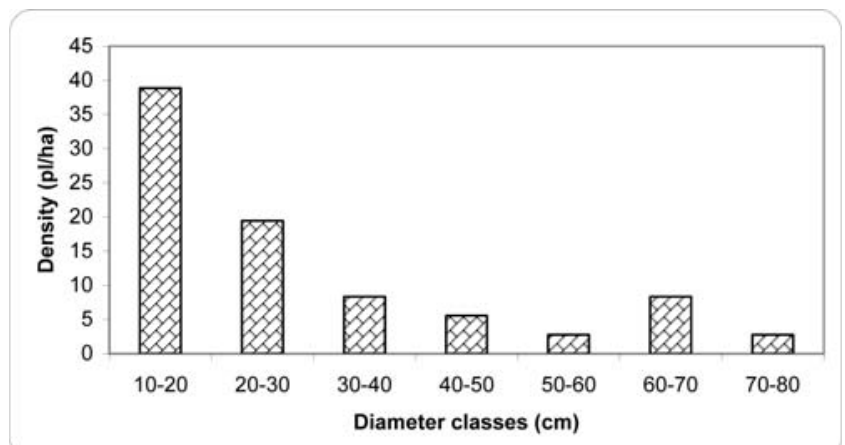

Figure 7: Density of different diameter classes of trees of Terminalia alata at SW slope

inception of community management. But people can graze Their domestic cattle without any restriction. To safe guard and monitor forest the FUGs had kept two forest-guards to patrol the forest area on payment basis. There are several 

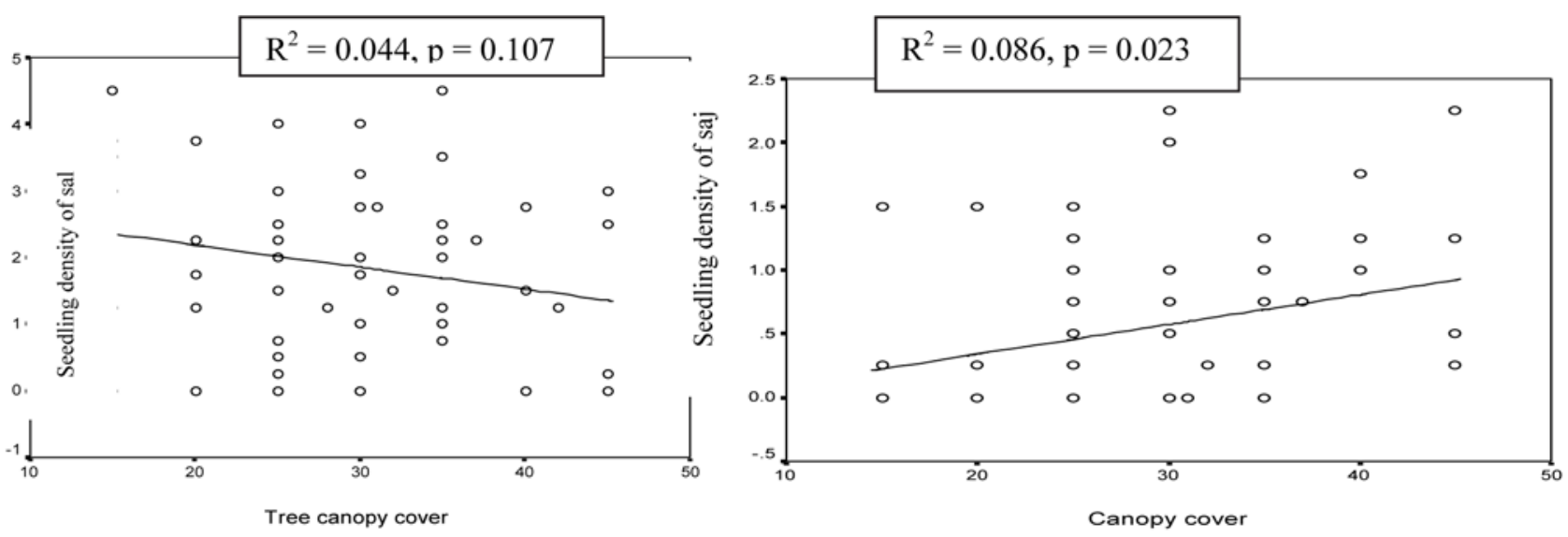

Figure 8: Relation between seedling density of sal (Shorea robusta) and saj (Terminalia alata) with tree canopy cover. The fitted lines are based on the linear regression.

practices prevalent in the area for conservation of forest resources. Some of them include construction of fireline to prevent accidental damage to forest by fire. There are laws and regulation to check illegal poaching of timber and fuelwood. Provisions are made to punish such culprits. The laws are however, poorly implemented. Members of the committee frequently monitor forest resources against such activities They distribute the plant like Khayar (Acacia Catechu), Amala (Phyllanthus emblica), Bakaino (Melia azedarach), Kadam (Anthocephallus cadambar), etc.from their own nursery to the FUGs to plant them in their own land as well as in public lands to reduce the dependency of people on forest for fuel wood .PCF had established nursery but it has already closed. They help at least Rs. 2,000 if any forest user group (FUG) want to installed biogas plant. Participation of sampled households represented that the degree of people's participation was not exciting. People were motivated more to take benefit only rather to conserve it. Participation of FUGs members had been observed implantation activities. Participation of FUGs in meeting and fire control had also been observed very poor ( $<50 \%$ of sampled $\mathrm{HH})$. In spite forest user group committee conduct the people nearby the forest to wipeout forest on payment basis. Thinning process of PCF was demand driven i.e. thinning has been done for the production of additional amount of fuelwood. During thinning process, low quality timber species, shrubs \& climbers werw removed for fuelwood which was done before the development of tender/new shoot at the month of November to December. This additional amount supply of fuelwood helped to minimize the gap between fuel wood demand and supply form the collection of dead plant parts.

FUG had planted some NTFPs species like Neem (Azadirachta indica), Jamuno (Syzygium cumini), Safeda (Annona squamosa), Kurilo (Asparagus racemosus), Sarpagandha (Rauwolfia serpentina), etc. before one year. In PCF, plantation of species for NTFPs was very poor but FUG committee has been searching ways and fund for its plantation and extension. It indicated that the consciousness of FUGs members towards the forest protection and biodiversity conservation had been increased. Questionnaire survey among the local people and field evidence showed that fire was a major problem, which has inhibit the regeneration of forest. Most of the forest fire occurs accidentally due to careless activities of human. Forest fires were less common in recent year but were more frequent before the beginning of community managemen FUG also claimed that, after the development of CF, the events like grazing, forest fire and illegal cutting of trees decreased considerably.

\section{DISCUSSION}

In PCF the number of plant species at both sites were nearly equal i.e. 100 (23 trees, 45 shrubs and 32 herbs) at SE slope (South-East aspect) and 102 (21 trees, shrubs and 32 herbs) at SW slope (South-West aspect), however composition of plant species were different. For example Terminalia alata was the most dominant SE slope (Annex 1) and Shorea robusta at SW slope (Annex 2). Total density of the tree species in the study area ranged from 453 to $550 \mathrm{pl} / \mathrm{ha}$ (Annex 1 and 2) Which is lower than in Churia forest of Rupandehi district (1092 - 1153 pl/ha, Marasini 2003) and Bashyal (2005) in tropical forest of Palpa district ( $654 \mathrm{pl} / \mathrm{ha}$ ). This value was higher than the values reported for sal forest by Poudel (2000) in a tropical forest of Udayapur district (226.93 pl/ha), Shrestha (2003) in Barandabhar community forest of Chitwan district $(85-250 \mathrm{pl} / \mathrm{ha})$. The total tree density at both the sites was lower than in Arun River Basin (1125 pl/ha, Duwadee 2000), Shrestha (1997) in Churia forest of eastern Nepal (2189 pl/ha, Bhuju and Yonzon 2000), Chitrepani (Siwalik region) of Malkwan pur district (1326 pl/ha). The low density of Desmodium oojeinense may be due to its specific use for making plough by FUGs. The population of tree species like Acacia catechu, Pterocarpus marsupium, Tectona grandis, Dalbergia latifolia, etc. were lower, so they are rare species. So, such species should not be harvested during fodder collection by FUGs. The basal area is an important criteria for evaluating the timber production in forest ecosystem (Agrawalj, 1992) and maturity/age group of the forests. In contrast, the basal area of PCF was higher than in Saptura National Park (26.28 $\mathrm{m}^{2} / \mathrm{ha}$ ) (Khatri et al.j, 2004) but lower than the value (63.86 $\mathrm{m}^{2} / \mathrm{ha}$ ) reported by Bashyal (2005) for tropical forest of Palpa district. Shrub/sapling density ranged from $4138-4708 \mathrm{pl} / \mathrm{ha}$ which was similar to the reported 
range in Chitrepani, Makwanpur (1786 -5457 pl/ha, Shrestha 1997), Churia forest of Rupandehi district (4267 - $5222 \mathrm{pl} / \mathrm{ha}$, Marasini, 2003). Shrub density of PCF was higher than that of community and government managed forest of Udayapur district (2756.99 - 3132.07 pl/ha, Poudel 2000) but lower than that of Barandabhar community forest of Chitwan district (5880-5920 pl/ha, Shrestha, 2003). Occurrence of only one tree of Bauhinia purpurea but relatively higher density of its sapling may be due to frequent loping of $B$. purpurea saplings for fodder (Malla, 2004) and young leaves being eaten as vegetables by members of FUGs. Low abundance of Buchanania latifolia in sapling stage may be due to its wide use for making roof rafters in traditional houses. Among the herbs, Carex cruciata was the most dominant species and can also grow under closed canopy cover. The higher density of Cymbopogon pendulus among the grasses might be due to sunny and exposed area with open canopy because light availability is the most important environmental factor related to graminoid distribution (Pivello et al., 1999). Seedlings of tree species like Shorea robusta and Terminalia alata were frequently distributed with highest density among the seedlings of tree species.

\section{Species Number, Diversity and Regeneration}

A total of 125 species of vascular plants have been collected from a total of 0.7 ha sampling area. The number of tree species was less than that of the number of shrub and herb species but the number of shrub species was found higher than the number of herb species (Table 1). The high species number in the studied forest may be due to grazing by livestock, since mild disturbance may increase species richness (Connel, 1978: Petraitis et al., 1989).In the studied forest, high species diversity may be due to high species evenness. The high value of $\mathrm{H}$ at $\mathrm{SW}$ slope was related with high species evenness (Table 1). The value of $\mathrm{H}$ (Table 1) was with in the range of value reported by Duwadee et al (2002) in lower Arun river basin forest of Makalu Barun Buffer Zone (1.64-2.89), Niroula (2004) in Siwalik hills of Ilam (1.74-2.78) but the value was lower than the value reported by Marasini (2003) in Churia forest of Rupandehi (3.12-4.19), Bashyal (2005) in tropical forest of Palpa district (2.08-4.1). Species richness was found highest in forest opened for cattle grazing by Gautam and Watanable (2005) in the hill forests of Gulmi district. The disturbances in the vegetation as grazing by animals, grass cutting and other resource harvest practices decrease the dominance of a few plants by making the environment suitable for invasion of other plants that increase species richness of an area (Collins et al. 1998 and Gough and Grace 1998) than shrubs in Churia forest of Rupandehi district. In the present studied forests, species evenness was higher at SW slope for all life forms (Table 1). The higher species diversity at both sites suggested that nearly equal contribution of several species (high species evenness) increased the species diversity. In the present studied forest species evenness was less for tree layer than for shrub layer. Similar result was reported by Bashyal (2005) in tropical forest of Palpa district. The diversity Index $(\mathrm{H})$ of Shrub was slightly higher than that of tree and herb (Table1) which was due to high species richness of shrub than tree and herb. In the present study, the highest index of dominance value $(\mathrm{C}=0.20)$ was recorded for tree layer at $\mathrm{SE}$ slope the index of dominance for trees was higher than the value $(\mathrm{C}=0.07)$ for tree layer in Saptura National Park (Khatri et al. 2004). In the present study area, alpha $(\alpha)$ diversity was higher at SE slope than at SW slope for all life forms. The alpha diversity was higher for shrub layer at SE slope than tree and herb layer. In the present study area, beta (â) diversity was found to be higher for tree layer at both sites. The low difference in beta diversity of tree, shrub and herb layer (Table 2) indicated that all growth forms responded to environmental factors in similar fashion (Adhikari et al., 1991).Combination of seedling/sapling count and analysis of size class diagram may give actual situation of reproduction (i.e. production of viable seed) and regeneration pattern. The reverse J-shaped size class distribution (except $S$. robusta at SW slope) (Figure 4, 5, 6 \& 7) of Shorea robusta and Terminalia alata in the studied forest indicates sustainable regeneration (Vetaas, 2000). However bell shaped size class distribution of $S$. robusta at SW slope (figure 6) indicates the lack of sustainable regeneration (Vetaas, 2000). It may be due to severe disturbances at that slopes in the past before conservation. But the higher density of sapling and seedling of S. robusta and T. alata (Annex 3, 4, 5 \& 6) at both the slopes showed the regeneration potential was fairly high of these species. Seedling of S. robusta was abundantly present which may be due to thin litter and open canopy. But T. alata had less number of seedling at both slopes (figure $2 \& 3$ ). Seeds of T. alata are more palatable for goats and sheeps than $S$. robusta. Palatable nature of seed and poor resistance of seedling of $T$. alata against the fire may be the main cause for the less number of its seedling. With the increase of tree canopy cover seedling density of Terminalia alata was found to increase (figure 8 ) as it favors to grow at moderate side shade but killed by more than one year of heavy over head shade (Jackson 1994). Seedling of Shorea robusta is light demander, so its number was found to increase with the decreasing tree canopy cover (Figure 8). Felling of live trees for timber also created canopy gap and promote regeneration of $S$. robusta by increasing light penetration. Thus seedlings of Terminalia alata and Shorea robusta were spatially reported in the community which may reduce competition between them. It has been reported that seedlings of T. alata favors to grow at moderate side shade but killed by more than one year of heavy over head shade (Jackson 1994). Seedling of Shorea robusta is light demander, so its number was found to increase with the decreasing shrub density and tree canopy cover (Figure 10). Thus seedlings of Terminalia alata and Shorea robusta were spatially reported in the community which may reduce competition between them. It was observed that during the summer season, there was damage to seedling and tender/new shoot due to fodder collection, grazing and forest fire as well. Due to this reason, the seedlings were unable to grow into young plant which results in the decrease of the regeneration of these plants. Since a long time, there has been a system of free grazing and collection of fodder throughout the year. Trampling and browsing by livestock (Glatzel, 1999; Roder et al., 2002) and 
fodder collection leads to the destruction of seedling and sapling, therefore, the density of small diameter classes is low in the forests opened to grazing (Gautam and Watanable, 2004). The local people were aware of the negative impact of grazing and fodder collection to forest regeneration. Nowadays, fodder collection has limited only twice a week throughout the year but free grazing was a common practice in present days too. It would be better to ban grazing during the months of seed germination and new growth or completely ban throughout the year to enhance the natural regeneration. People in the study area depend on forest resources for their subsistence livelihood, primarily as a source fuelwood and fodder. It can be inferred that present forest management strategy has been mainly directed towards the production of wood products. To meet ambitions o0f FUGs, the only easily attainable and viable option they had choosen was extraction of timber to raise the fund. Recent evidence indicates that CFUGs are slowly moving towards active forest management, since the desire to protect forest was observed stronger than before. Concerned efforts by government agencies and nongovernment organizations to provide support services for integrating indigenous knowledge may motivate people to grow more trees on agricultural land (Paudel, 2003), thereby, reducing pressure on forest. Adoption of active forest management activities by empowering the CFUGs seemed to be promoted. Issues related to external influences and other disturbances in the forest could be solved through the concerned authorities of that area. Forest improvement is an indicator to measure the success of Nepal's community forestry program (Pokharel, 2003). On the other hand, through good production of NTFPs and timber as a result of the sustainable management of CF could provide an additional opportunity to the local users in developing their villages and communities to fulfill their basic needs from the forest.

\section{CONCLUSION}

After the handover of the forest to the community, the condition of PCF has been improving as the forest contain good forest stocking indicated by its higher species diversity and species richness, high natural regeneration potential and moderate/good shape of trees. The forest is dominated by Shorea robusta and Terminalia alata favored by acidic soil. Natural regeneration potential of $S$. robusta is high, in spite of pressure of intensive grazing, forest fire and high pressure of resource use. To get more benefits and achieve better management of the forest, there is a need to control free grazing in the forest. Due to increased demand of FPs, the existing operational forest management plans do not seem to be fully functional. So, the effective implementation of the operational plan as approved by DFO, is necessary. Finally, active forest management of PCF by CFUGs can lead to an increased supply of forest products (FPs) resulting in increased benefits to users to fulfill the requirement of FPs.

\section{ACKNOWLEDGEMENTS}

We are thankful to local respondence of the community forest for shearing valuable informations. We also thanks the authorities of PCF for giving permission to work in the forest. We are really very greatful to our sister Ramita Acharya, Rohit Paudel, Mahadev Chaudhary and Bishwanath Chaudhary, The member FUGs of PCF for their help in field work. I also indebted to my friend Amar Nath Sharma for his help in computer work.

Annex-1: Density (D, Pl/ha), Relative Density (RD, \%), Frequency (F, \%), Relative Frequency (RF, \%), Basal Area (BA, m²/ha), Relative Basal Area (RBA, \%) and Importance Value Index (IVI) of tree species at SE slope

\begin{tabular}{|c|c|c|c|c|c|c|c|c|}
\hline SN & Name of the species & $\begin{array}{c}\text { D } \\
\text { (pl/ha) }\end{array}$ & $\begin{array}{l}\text { RD } \\
(\%) \\
\end{array}$ & $\begin{array}{c}\mathbf{F} \\
(\%)\end{array}$ & $\begin{array}{l}\text { RF } \\
(\%)\end{array}$ & $\begin{array}{c}\text { BA } \\
\left(\mathrm{m}^{2} / \mathrm{ha}\right)\end{array}$ & $\begin{array}{c}\text { RBA } \\
(\%)\end{array}$ & IVI \\
\hline 1 & Terminalia alata & 150 & 27.27 & 77.77 & 26.17 & 11.77 & 39.66 & 93.12 \\
\hline 2 & Shorea robusta & 177.77 & 32.32 & 50 & 16.83 & 5.61 & 18.91 & 68.07 \\
\hline 3 & Anogeissus latifolia & 61.11 & 11.11 & 41.66 & 14.02 & 5.51 & 18.56 & 43.698 \\
\hline 4 & Lagerstroemia parviflora & 38.88 & 7.07 & 33.33 & 11.21 & 0.57 & 1.92 & 20.215 \\
\hline 5 & Buchanania latifolia & 25 & 4.54 & 22.22 & 7.47 & 1.31 & 4.41 & 16.44 \\
\hline 6 & Adina cordifolia & 25 & 4.54 & 2.77 & 0.93 & 1.730 & 5.82 & 11.30 \\
\hline 7 & Semecarpus anacardium & 11.11 & 2.02 & 11.11 & 3.73 & 0.222 & 0.74 & 6.50 \\
\hline 8 & Mangifera indica & 2.77 & 0.50 & 2.77 & 0.93 & 0.836 & 2.81 & 4.25 \\
\hline 9 & Dalbergia latifolia & 5.55 & 1.00 & 5.55 & 1.86 & 0.172 & 0.57 & 3.45 \\
\hline 10 & Hydrangea sp. & 5.55 & 1.00 & 5.55 & 1.86 & 0.122 & 0.41 & 3.28 \\
\hline 11 & Schleichera oleosa & 2.77 & 0.50 & 2.77 & 0.93 & 0.529 & 1.78 & 3.21 \\
\hline 12 & Diospyros tomentosa & 5.55 & 1.00 & 5.55 & 1.86 & 0.086 & 0.28 & 3.16 \\
\hline 13 & Miliusa tomentosa & 5.55 & 1.00 & 5.55 & 1.86 & 0.080 & 0.26 & 3.14 \\
\hline 14 & Wendlandia puberula & 5.55 & 1.00 & 5.55 & 1.86 & 0.058 & 0.19 & 3.07 \\
\hline 15 & Desmodium oojeinense & 2.77 & 0.50 & 2.77 & 0.93 & 0.326 & 1.09 & 2.53 \\
\hline 16 & Acacia catechu & 5.55 & 1.00 & 2.77 & 0.93 & 0.174 & 0.58 & 2.52 \\
\hline 17 & Phyllanthus emblica & 2.77 & 0.50 & 2.77 & 0.93 & 0.188 & 0.63 & 2.06 \\
\hline 18 & Cassia fistula & 2.77 & 0.50 & 2.77 & 0.93 & 0.157 & 0.52 & 1.96 \\
\hline 19 & Stereospermum chelonoides & 2.77 & 0.50 & 2.77 & 0.93 & 0.080 & 0.26 & 1.70 \\
\hline 20 & Zizyphus incurve & 2.77 & 0.50 & 2.77 & 0.93 & 0.060 & 0.20 & 1.63 \\
\hline 21 & Mallotus philippinensis & 2.77 & 0.50 & 2.77 & 0.93 & 0.038 & 0.12 & 1.56 \\
\hline 22 & Bauhinia purpurea & 2.77 & 0.50 & 2.77 & 0.93 & 0.033 & 0.11 & 1.54 \\
\hline 23 & Aesandra butyracea & 2.77 & 0.50 & 2.77 & 0.93 & 0.019 & 0.06 & 1.49 \\
\hline \multicolumn{2}{|r|}{ Total } & 549.87 & 99.88 & 297.08 & 100 & 29.68 & 100 & 299.982 \\
\hline
\end{tabular}


Annex -2: Density (D, Pl/ha), Relative Density (RD, \%), Frequency (F, \%), Relative Frequency (RF, \%), Basal Area (BA, m²/ha), Relative Basal Area (RBA, \%) and Importance Value Index (IVI) of tree species at SW slope

\begin{tabular}{|c|c|c|c|c|c|c|c|c|}
\hline SN & Name of the species & $\begin{array}{c}\mathbf{D} \\
(\mathrm{pl} / \mathrm{ha})\end{array}$ & $\begin{array}{l}\text { RD } \\
(\%)\end{array}$ & $\begin{array}{c}F \\
(\%)\end{array}$ & $\begin{array}{l}\text { RF } \\
(\%)\end{array}$ & $\begin{array}{c}\text { BA } \\
\left(\mathrm{m}^{2} / \mathbf{h a}\right)\end{array}$ & $\begin{array}{l}\text { RBA } \\
(\%)\end{array}$ & IVI \\
\hline 1 & Shorea robusta & 172.22 & 38.04 & 80.55 & 27.11 & 26.47 & 62.04 & 127.20 \\
\hline 2 & Terminalia alata & 86.11 & 19.02 & 44.44 & 14.95 & 7.96 & 18.66 & 52.64 \\
\hline 3 & Anogeissus latifolia & 36.11 & 7.97 & 33.33 & 11.21 & 2.23 & 5.24 & 24.43 \\
\hline 4 & Lagerstroemia parviflora & 19.44 & 6.74 & 16.66 & 9.34 & 0.39 & 1.57 & 20.83 \\
\hline 5 & Semecarpus anacardium & 30.55 & 6.13 & 27.77 & 8.41 & 0.67 & 2.20 & 17.67 \\
\hline 6 & Buchanania latifolia & 27.77 & 4.29 & 25 & 5.60 & .94 & 0.93 & 16.93 \\
\hline 7 & Wendlandia coriacea & 13.88 & 3.06 & 11.11 & 3.73 & 0.21 & 0.51 & 7.20 \\
\hline 8 & Adina codifolia & 8.33 & 1.84 & 8.33 & 2.80 & 0.86 & 2.01 & 6.65 \\
\hline 9 & Desmodium oojeinense & 8.33 & 2.45 & 5.55 & 2.80 & 1.10 & 0.27 & 6.29 \\
\hline 10 & Cormus oblonga & 11.11 & 1.84 & 8.33 & 2.80 & 0.11 & 0.30 & 5.52 \\
\hline 11 & Diospyros tomentosa & 8.33 & 1.84 & 8.33 & 1.86 & 0.13 & 2.58 & 4.94 \\
\hline 12 & Schleichera oleosa & 2.77 & 1.22 & 2.77 & 0.93 & 0.72 & 0.96 & 3.23 \\
\hline 13 & Stereospermum chelonoides & 5.55 & 0.61 & 2.77 & 0.93 & 0.41 & 1.68 & 3.11 \\
\hline 14 & $\begin{array}{l}\text { Tectona grandis } \\
\text { Teration }\end{array}$ & 2.77 & 0.61 & 2.77 & 0.93 & 0.06 & 0.18 & 1.95 \\
\hline 15 & Mallotus philipinensis & 2.77 & 0.61 & 2.77 & 0.93 & 0.08 & 0.15 & 1.73 \\
\hline 16 & Terminalia chebula & 2.77 & 0.61 & 2.77 & 0.93 & 0.06 & 0.14 & 1.69 \\
\hline 17 & Hymenodictyon excelsum & 2.77 & 0.61 & 2.77 & 0.93 & 0.05 & 0.13 & 1.67 \\
\hline 18 & Pterocarpus marsupium & 2.77 & 0.61 & 2.77 & 0.93 & 0.05 & 0.13 & 1.67 \\
\hline 19 & Phyllanthus emblica & 2.77 & 0.61 & 2.77 & 0.93 & 0.04 & 0.11 & 1.65 \\
\hline 20 & Miliusa tomentosa & 2.77 & 0.61 & 2.77 & 0.93 & 42.67 & 0.07 & 1.58 \\
\hline 21 & Syzygium cumini & 2.77 & 0.61 & 2.77 & 0.93 & 0.03 & 0.14 & 1.31 \\
\hline & Total & 452.66 & 99.98 & 297.1 & 99.99 & 42.67 & 100 & 299.97 \\
\hline
\end{tabular}

\section{REFERENCES}

Acharya, K.P. 2003. Changing strategy for community forestry in Nepal: The case for active management. The Journal of Forest Policy. 10(1): 43-45.

Agrawal, S.K. 1992. Fundamental of Ecology. Ashish publishing House, New Delhi, 216 p.

Anonymous 2007. Rupandehi jilla ek parichaya (In Nepali) District development committee, Rupoandehi District, Nepal.

Bashyal, S. 2005. Quantitative analysis and regeneration of Shorea robusta and Terminalia alata of tropical forest in Palpa district. M.Sc. thesis. Central Department of Botany, Tribhuvan University, Kathmandu, Nepal. 74 p.

Connel, J.H. 1978. Diversity in tropical rain forest and coral reefs. Science 199: 1302-1330.

Duwadee, N.P.S., R.P. Chaudhary, V.N.P. Gupta and O.R. Vetaas. 2002. Species diversity of Shorea robusta forest in lower basin of Makalu Barun National Park, Nepal. In: (eds. RP Chaudhary, BP Subedi, OR Vetaas and TH Aase), Vegetation and Society: their interactions in the Himalayas. pp. 56-64.

Fatubarin, A. 1987.Obsevation on the natural regeneration of the woody plants in a savanna ecosystem in Nigeria. Tropical Ecology:28:1-8

Gautam, C.M. and T. Watanable. 2004. Land cover change in Himalaya with special reference to forest disturbance: a case of Bharse area, Lesser Himalaya, West Central Nepal. Himalayan Journal of Sciences 2(4): 138-139.

Glatzel, G. 1999. Historic forest use and its possible implication to recently accelerated tree growth in Central Europe. In: Karjalainen T, H Spieker, O Laroussine (eds.), Causes and consequences of accelerated tree growth in Europe. Joensuu, Finland: European Forest Institute. 65-74 p.

GoN. 2007. Community forestry: Achievements and limitations in the Mid-Western region. Kathmandu: Department of Forest. Community Forestry Division Government of Nepal. Community Forestry Bulleting 12: 17-34.

Jackson, J.K. 1994. Manual of afforestation in Nepal. Vol I and II. Forest Research and Survey center, Kathmandu, Nepal.
Khatri, P.K., N.G. Totey and R.K. Pandey. 2004. Altitudinal variation in Satpura National Park. Indian Forester 130: 1141-1154.

Magurran. A.E. 2004. Measuring Biological Diversity. Blackwell Publishing, United Kingdom, 256 p.

Malla, M.B. 2004. Chemical composition and feed value of fodder trees from Palpa district, Nepal. Banko Jankari 14(1): 27-30

Marasini, S. 2003. Vegetation analysis of churiya forest in Rupandehi, Nepal. M.Sc. thesis. Central Department of Botany, Tribhuvan University, Kathmandu, Nepal. 91 p.

Metz, J.J. 1991. Vegetation assessment and research methods for community forestry in Nepal. A working paper submitted to the Environment and Policy Institute, East-West center, Honolu, Hawaii.

MoPE. 2004. National action programme on land degradation and desertification in the context of the UN convention to combat desertification. Ministry of population and environment, Kathmandu, Nepal.

Nightiangle, A.J. 2002. Participation or just sitting in? The dynamics of gender and caste in community forestry. Journal of Forest and Livelihood 2(1): 17-24.

Niroula, R.K. 2004. Phytodiversity and soil study of Siwalik Hills of Illam, Nepal. M.Sc. thesis. Central Department of Botany, Tribhuvan University, Kathmandu, Nepal. 78 p.

NPC. 2001. Midterm evaluation of the Ninth Five Year Plan. National Planning Commission, Kathmandu, Nepal.

Paudel, A. 2006. Assessment of the status of the floral diversity and the management practices (A case study in Hasantar community forest, Lalitpur). M.Sc. thesis. Central Department of Environmental Science, Tribhuvan University, Kathmandu, Nepal. 60 p.

Petraitis, P.S., RE Lathamm and RA Niesenbau. 1989. The maintenance of species diversity by disturbance. Quarterly Review of Biology 64: 393-418.

Pivello, V.R., N.S. Claudia and TM Sorgio (1999). Alien grasses in Brazilian Savanas: A threat to Biodiversity. Biodiversity and Conservation 8(9): 1281-1894.

Pokharel, B.K. and Nurse, M. 2005. Forests and people's livelihood: Benefiting the poor from community forestry. Journal of Forest and Livelihood 4: 19-20. 
Annex-3: Density (D pl/ha), Relative Density (RD, \%), Frequency (F, \%), Relative Frequency (RF, \%), Coverage (C, \%), Relative Coverage (RC, \%) and Importance Value Index (IVI) of shrub layer at SE slope.

\begin{tabular}{|c|c|c|c|c|c|c|c|c|}
\hline SN & Name of the species & $\mathrm{D}(\mathrm{pl} / \mathrm{ha})$ & RD (\%) & $F(\%)$ & RF (\%) & $\mathrm{C}(\%)$ & $\mathrm{RC}(\%)$ & IVI \\
\hline \multicolumn{9}{|c|}{ Shrubs } \\
\hline 1 & Phoenix humilis & 544.44 & 11.56 & 45.83 & 8.62 & 7.29 & 10.23 & 30.416 \\
\hline 2 & Barleria strigosa & 422.22 & 8.96 & 31.94 & 6.0 & 3.75 & 5.26 & 20.237 \\
\hline 3 & Millettia extensa & 311.11 & 6.60 & 25.00 & 4.70 & 4.2 & 5.89 & 17.201 \\
\hline 4 & Leea macrophylla & 238.88 & 5.07 & 30.55 & 5.74 & 2.67 & 3.74 & 14.56 \\
\hline 5 & Leea indica & 216.66 & 4.60 & 16.66 & 3.13 & 2.32 & 3.25 & 10.96 \\
\hline 6 & Woodfordia fruticosa & 100 & 2.12 & 22.22 & 4.18 & 2.32 & 3.25 & 9.55 \\
\hline 7 & Grewia angustifolia & 161.11 & 3.42 & 18.05 & 3.39 & 1.35 & 1.89 & 8.70 \\
\hline 8 & Bauhinia vahlii & 66.66 & 1.41 & 11.11 & 2.09 & 2.46 & 0.82 & 6.94 \\
\hline 9 & Indigofera pulchella & 61.11 & 1.29 & 8.33 & 1.56 & 1.14 & 1.60 & 4.46 \\
\hline 10 & Flemingia macrophylla & 72.22 & 1.53 & 8.33 & 1.56 & 0.59 & 0.82 & 3.92 \\
\hline 11 & Marsdenia tinctoria & 66.66 & 1.41 & 5.55 & 1.04 & 0.90 & 1.26 & 3.71 \\
\hline 12 & Phyllodium pulchellum & 50.00 & 1.06 & 6.94 & 1.30 & 0.72 & 1.01 & 3.37 \\
\hline 13 & Helicteres isora & 38.88 & 0.82 & 6.94 & 1.30 & 0.34 & 0.47 & 2.60 \\
\hline 14 & Colebrookea oppositifolia & 27.77 & 0.58 & 5.55 & 1.04 & 0.65 & 0.91 & 2.54 \\
\hline 15 & Grewia tiliaefolia & 5.55 & 3.42 & 1.38 & 3.39 & 1.35 & 1.89 & 2.22 \\
\hline 16 & Ampelocissus divericata & 27.77 & 0.58 & 5.55 & 1.04 & 0.31 & 0.43 & 2.06 \\
\hline 17 & Spatholobus parviflorus & 16.66 & 0.35 & 4.16 & 0.78 & 0.45 & 0.63 & 1.76 \\
\hline 18 & Xeromphis spinosa & 16.66 & 0.35 & 4.16 & 0.78 & 0.45 & 0.63 & 1.76 \\
\hline 19 & Jasminum officinalae & 16.66 & 0.15 & 4.16 & 0.78 & 0.31 & 0.43 & 1.56 \\
\hline 20 & Combretum roxburghii & 16.66 & 0.35 & 2.77 & 0.52 & 0.41 & 0.57 & 1.44 \\
\hline 21 & Sida cordata & 22.22 & 0.47 & 4.16 & 0.78 & 0.13 & 0.18 & 1.43 \\
\hline 22 & Asparagus racemosus & 22.22 & 0.47 & 4.16 & 0.78 & 0.10 & 0.14 & 1.39 \\
\hline 23 & Pavetta tomentosa & 11.11 & 0.23 & 2.77 & 0.52 & 0.41 & 0.57 & 1.32 \\
\hline 24 & Phyllanthus reticulatus & 16.66 & 0.35 & 4.16 & 0.78 & 0.13 & 0.18 & 1.31 \\
\hline 25 & Reissantia arborea & 16.66 & 0.35 & 2.77 & 0.52 & 0.24 & 0.33 & 1.20 \\
\hline 26 & Cissus repens & 11.11 & 0.23 & 2.77 & 0.52 & 0.24 & 0.33 & 1.08 \\
\hline 27 & Xylosoma controversum & 11.11 & 0.23 & 2.77 & 0.52 & 0.24 & 0.33 & 1.08 \\
\hline 28 & Urena lobata & 22.22 & 0.47 & 2.77 & 0.52 & 0.06 & 0.08 & 1.07 \\
\hline 29 & Bridelia retusa & 5.55 & 0.11 & 1.38 & 0.25 & 0.41 & 0.57 & 0.94 \\
\hline 30 & Clausena sp. & 11.11 & 0.23 & 2.77 & 0.52 & 0.06 & 0.08 & 0.83 \\
\hline 31 & Inula cappa & 11.11 & 0.23 & 2.77 & 0.52 & 0.06 & 0.08 & 0.83 \\
\hline 32 & Smilax ovalifolia & 11.11 & 0.23 & 1.38 & 0.25 & 0.20 & 0.28 & 0.77 \\
\hline 33 & Glochidion sp. & 5.55 & 0.11 & 1.38 & 0.25 & 0.20 & 0.28 & 0.65 \\
\hline 34 & Phlogacanthus thyrsiflorus & 5.55 & 0.11 & 1.38 & 0.25 & 0.20 & 0.28 & 0.65 \\
\hline 35 & Desmodium gangeticum & 11.11 & 0.23 & 1.38 & 0.25 & 0.03 & 0.04 & 0.53 \\
\hline 36 & Antidesma acuminatum & 5.55 & 0.11 & 1.38 & 0.25 & 0.03 & 0.04 & 0.41 \\
\hline 37 & Ardisia solanacea & 5.55 & 0.11 & 1.38 & 0.25 & 0.03 & 0.04 & 0.41 \\
\hline 38 & Camylotropis speciosa & 5.55 & 0.11 & 1.38 & 0.25 & 0.03 & 0.04 & 0.41 \\
\hline 39 & Desmodium laxiflorum & 5.55 & 0.11 & 1.38 & 0.25 & 0.03 & 0.04 & 0.41 \\
\hline 40 & Mimosa rubicaulis & 5.55 & 0.11 & 1.38 & 0.25 & 0.20 & 0.28 & 0.41 \\
\hline 41 & Paederia foetidia & 5.55 & 0.11 & 1.38 & 0.25 & 0.03 & 0.04 & 0.41 \\
\hline 42 & Premna integrifolia & 5.55 & 0.11 & 1.38 & 0.25 & 0.03 & 0.04 & 0.41 \\
\hline 43 & Thespesia lampas & 5.55 & 0.11 & 1.38 & 0.25 & 0.03 & 0.04 & 0.41 \\
\hline \multicolumn{9}{|c|}{ Tree Saplings } \\
\hline 44 & Shorea robusta & 1227.77 & 26.07 & 61.11 & 11.49 & 14.97 & 21.01 & 58.585 \\
\hline 45 & Terminalia alata & 369.44 & 7.84 & 69.44 & 13.06 & 10.9 & 15.30 & 36.21 \\
\hline 46 & Lagerstroemia parviflora & 72.22 & 1.53 & 12.5 & 2.35 & 2.18 & 3.06 & 6.934 \\
\hline 47 & Holarhena pubscens & 44.44 & 2.60 & 9.72 & 1.82 & 1.31 & 1.83 & 6.259 \\
\hline 48 & Zizyphus incurva & 33.33 & 0.70 & 6.94 & 1.30 & 0.55 & 0.47 & 2.782 \\
\hline 49 & Semecarpus anacardium & 27.77 & 0.58 & 6.94 & 1.30 & 0.52 & 0.73 & 2.614 \\
\hline 50 & Mallotus philippinensis & 22.22 & 0.47 & 5.55 & 1.04 & 0.62 & 0.87 & 2.373 \\
\hline 51 & Miliusa tomentosa & 16.66 & 0.35 & 4.16 & 0.78 & 0.45 & 0.37 & 1.765 \\
\hline 52 & Anogeissus latifolia & 22.22 & 0.47 & 4.16 & 0.78 & 0.27 & 0.37 & 1.623 \\
\hline 53 & Buchanania latifolia & 11.11 & 0.23 & 2.77 & 0.52 & 0.55 & 0.77 & 1.526 \\
\hline 54 & Cormus oblonga & 16.66 & 0.35 & 4.16 & 0.78 & 0.27 & 0.37 & 1.505 \\
\hline 55 & Wendlandia puberula & 11.11 & 0.23 & 2.77 & 0.52 & 0.62 & 0.87 & 1.426 \\
\hline 56 & Diospyros tomentosa & 16.66 & 0.35 & 2.77 & 0.52 & 0.24 & 0.33 & 1.204 \\
\hline 57 & Adina cordifolia & 11.11 & 0.23 & 2.77 & 0.52 & 0.24 & 0.08 & 1.086 \\
\hline 58 & Aegle marmelos & 16.66 & 0.35 & 2.77 & 0.52 & 0.03 & 0.04 & 0.914 \\
\hline 59 & Cassia fistula & 11.11 & 0.23 & 2.77 & 0.52 & 0.10 & 0.14 & 0.896 \\
\hline 60 & Dalbergia latifolia & 11.11 & 0.23 & 2.77 & 0.52 & 0.06 & 0.08 & 0.836 \\
\hline 61 & Bauhinia purpurea & 11.11 & 0.23 & 2.77 & 0.52 & 0.06 & 0.08 & 0.826 \\
\hline 62 & Desmodium oojeinense & 5.55 & 0.11 & 1.38 & 0.25 & 0.03 & 0.04 & 0.416 \\
\hline 63 & Ficus racemosa & 5.55 & 0.11 & 1.38 & 0.25 & 0.03 & 0.04 & 0.416 \\
\hline 64 & Phyllanthus emblica & 5.55 & 0.11 & 1.38 & 0.25 & 0.03 & 0.04 & 0.416 \\
\hline 65 & Schleichera oleosa & 5.55 & 0.11 & 1.38 & 0.25 & 0.03 & 0.04 & 0.416 \\
\hline 66 & Sterculia villosa & 16.66 & 0.35 & 4.16 & 0.78 & 0.06 & 0.08 & 0.416 \\
\hline & Total & 4708.05 & 99.98 & 531.51 & 100 & 95.52 & 99.96 & 299.94 \\
\hline
\end{tabular}


Annex-4: Density (D, pl/ha), Relative Density (RD, \%), Frequency (F, \%), Relative Frequency (RF, \%), Coverage (C, \%), Relative Coverage (RC, \%) and Importance Value Index (IVI) of Shrub layer at SW slope

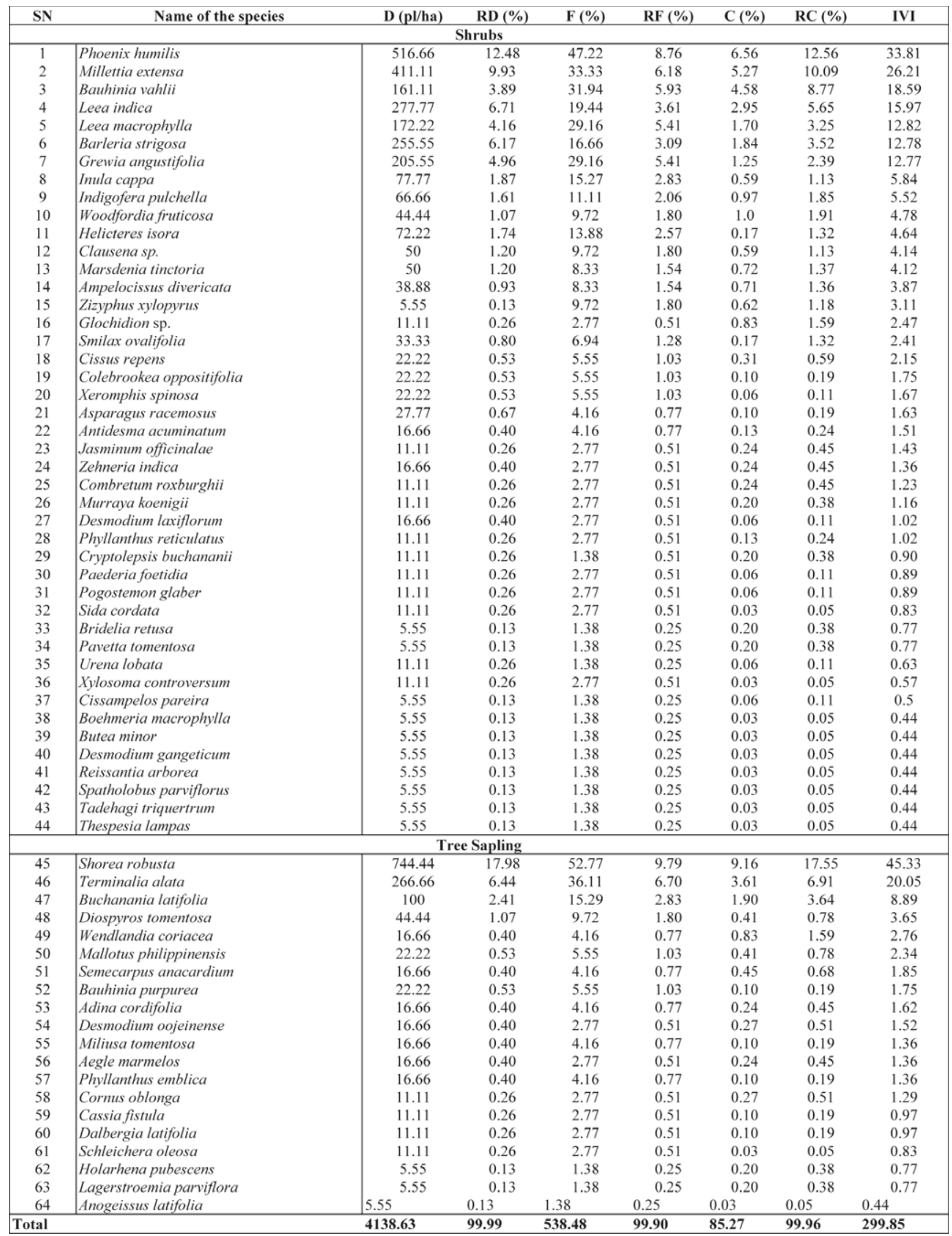


Annex-5: Density (D, pl/m²), Relative Density (RD, \%), Frequency (F \%), Relative Frequency (RF, \%), Coverage (C, \%), Relative Coverage (RC, \%) and Importance Value Index (IVI) of herb layer at SE slope

\begin{tabular}{|c|c|c|c|c|c|c|c|c|}
\hline SN & Name of the species & $\begin{array}{c}\mathbf{D} \\
\left(\mathrm{pl} / \mathrm{m}^{2}\right)\end{array}$ & $\begin{array}{l}\text { RD } \\
(\%) \\
\end{array}$ & $\begin{array}{c}F \\
(\%)\end{array}$ & $\begin{array}{l}\text { RF } \\
(\%)\end{array}$ & $\begin{array}{c}\mathrm{C} \\
(\%)\end{array}$ & $\begin{array}{l}\mathrm{RC} \\
(\%)\end{array}$ & IVI \\
\hline \multicolumn{9}{|c|}{ Herbs } \\
\hline 1 & Carex cruciata & 3.02 & 27.87 & 56.25 & 14.31 & 4.94 & 11.08 & 53.27 \\
\hline 2 & Eranthemum cilatum & 1.79 & 16.49 & 50 & 12.72 & 7.29 & 16.35 & 45.56 \\
\hline 3 & Cymbopogon pendulus & 0.88 & 8.11 & 28.47 & 7.24 & 8.83 & 19.80 & 35.17 \\
\hline 4 & Eulaliopsis binnata & 0.36 & 3.32 & 12.5 & 3.18 & 3.24 & 7.26 & 13.77 \\
\hline 5 & Curculigo orchioides & 0.40 & 3.77 & 18.75 & 4.77 & 1.57 & 3.52 & 12.06 \\
\hline 6 & Capillipediuna assimilis & 0.20 & 1.85 & 6.25 & 1.59 & 1.26 & 2.82 & 6.27 \\
\hline 7 & Heteropogon contortus & 0.22 & 2.04 & 7.63 & 1.94 & 0.88 & 1.97 & 5.96 \\
\hline 8 & Globba racemosa & 0.13 & 1.27 & 5.55 & 1.41 & 0.36 & 0.80 & 3.49 \\
\hline 9 & Eragrostis tenella & 0.13 & 1.27 & 5.55 & 1.41 & 0.24 & 0.53 & 3.22 \\
\hline 10 & Adiantum philipense & 0.13 & 1.21 & 4.16 & 1.18 & 0.12 & 0.26 & 2.67 \\
\hline 11 & Rungia parviflora & 0.13 & 1.21 & 2.77 & 0.70 & 0.22 & 0.49 & 2.41 \\
\hline 12 & Lygodium flexuosum & 0.06 & 0.63 & 5.55 & 1.41 & 0.13 & 0.29 & 2.34 \\
\hline 13 & Chlorophytum neplense & 0.04 & 0.44 & 3.47 & 0.88 & 0.19 & 0.42 & 1.75 \\
\hline 14 & Dioscorea hispida & 0.04 & 0.38 & 4.16 & 1.18 & 0.08 & 0.17 & 1.75 \\
\hline 15 & Curcuma aromatica & 0.03 & 0.31 & 2.77 & 0.70 & 0.22 & 0.49 & 1.51 \\
\hline 16 & Arisaema tortuosum & 0.0002 & 0.001 & 2.08 & 0.52 & 0.31 & 0.69 & 1.22 \\
\hline 17 & Chrysopogon aciculatus & 0.06 & 0.63 & 1.38 & 0.35 & 0.02 & 0.04 & 1.03 \\
\hline 18 & Colocassia fallax & 0.04 & 0.38 & 2.08 & 0.52 & 0.05 & 0.11 & 1.02 \\
\hline 19 & Costus speciosus & 0.01 & 0.12 & 1.38 & 0.35 & 0.20 & 0.44 & 0.92 \\
\hline 20 & Begonia picta & 0.0002 & 0.002 & 2.08 & 0.52 & 0.13 & 0.29 & 0.82 \\
\hline 21 & Oxalis corniculata & 0.03 & 0.31 & 1.38 & 0.35 & 0.03 & 0.06 & 0.73 \\
\hline 22 & Commelina benghalensis & 0.02 & 0.25 & 1.38 & 0.35 & 0.03 & 0.06 & 0.67 \\
\hline 23 & Discorea bulbifera & 0.02 & 0.19 & 1.38 & 0.35 & 0.05 & 0.11 & 0.65 \\
\hline 24 & Ageratum conyzoides & 0.02 & 0.19 & 1.38 & 0.35 & 0.03 & 0.06 & 0.60 \\
\hline 25 & Imperata cylindrica & 0.02 & 0.19 & 0.69 & 0.17 & 0.10 & 0.22 & 0.59 \\
\hline 26 & Dumosia villosa & 0.01 & 0.12 & 0.69 & 0.17 & 0.10 & 0.22 & 0.52 \\
\hline 27 & Saccharum spontaneum & 0.006 & 0.06 & 0.69 & 0.17 & 0.10 & 0.22 & 0.46 \\
\hline 28 & Arundinella nepalensis & 0.01 & 0.12 & 0.69 & 0.17 & 0.01 & 0.02 & 0.32 \\
\hline 29 & Cheilanthus bicolor & 0.01 & 0.12 & 0.69 & 0.17 & 0.01 & 0.02 & 0.32 \\
\hline 30 & Euphorbia parviflora & 0.01 & 0.12 & 0.69 & 0.17 & 0.01 & 0.02 & 0.32 \\
\hline 31 & Clerodendrum indicum & 0.006 & 0.06 & 0.69 & 0.17 & 0.01 & 0.02 & 0.26 \\
\hline 32 & Holmskioldia sanguinea & 0.006 & 0.06 & 0.69 & 0.17 & 0.01 & 0.02 & 0.26 \\
\hline \multicolumn{9}{|c|}{ Shrubs Seedling } \\
\hline 33 & Bauhinia vahlii & 0.06 & 0.63 & 13.88 & 3.53 & 0.22 & 0.49 & 4.66 \\
\hline 34 & Xeromphis spinosa & 0.08 & 0.76 & 6.25 & 1.59 & 0.32 & 0.71 & 3.07 \\
\hline 35 & Woodfordia fruticosa & 0.05 & 0.51 & 4.16 & 1.18 & 0.24 & 0.53 & 2.23 \\
\hline 36 & Millettia extensa & 0.03 & 0.31 & 3.47 & 0.88 & 0.15 & 0.33 & 1.53 \\
\hline 37 & Leea macrophylla & 0.020 & 0.19 & 2.08 & 0.52 & 0.05 & 0.11 & 0.83 \\
\hline 38 & Antidesma acumintum & 0.020 & 0.19 & 1.38 & 0.35 & 0.03 & 0.06 & 0.60 \\
\hline \multicolumn{9}{|c|}{ Trees Seedling } \\
\hline 39 & Shorea robusta & 1.52 & 14.00 & 63.88 & 16.26 & 6.92 & 15.52 & 45.78 \\
\hline 41 & Terminalia alata & 0.97 & 9.01 & 53.47 & 13.61 & 5 & 11.21 & 33.83 \\
\hline 42 & Buchanania latifolia & 0.05 & 0.51 & 5.55 & 1.41 & 0.48 & 1.07 & 2.99 \\
\hline 43 & Holarhena pubscens & 0.06 & 0.57 & 4.86 & 1.23 & 0.22 & 0.49 & 2.30 \\
\hline & Total & 10.86 & 100 & 392.85 & 100 & 44.58 & 99.91 & 299.91 \\
\hline
\end{tabular}

Pokharel, R. 2003. An evaluation of the community forestry program in Kaski district of Nepal: A local perspective. Unpublished Ph.D. dissertation, Michigan State University, USA.

Polunin O. and A. Stainton. 2000. Flowers of the Himalaya [fourth impression] New Delhi, (India): Oxford University Press. 545 p.

Poudel, S. 2000. Comparative study of vegetation structure and soil characteristics in community and government managed forest in Udayapur district, Nepal. M.Sc. thesis. Central Department of Botany, Tribhuvan University, Kathmandu, Nepal. 63 p.

Roder, W., G. Gratzer and K Wangdi. 2002. Cattle grazing in the conifer forests of Bhutan. Mountain Research and Development 22(4): 368-374.

Saxena, A.K. and J.S. Singh. 1984. Tree population structure of certain Himalayan forest associations and implications concerning their future composition. Vegetatis 58: 61-69.
Saxena, A.K., S.P. Singh and J.S. Singh. 1984. Population structure of forests of Kumaun Himalaya: Implication for management, Journal of Environmental Management 19: 307-324.

Shrestha, D.L. 2000. Present status of wood energy in Nepal. In: Woodfuel trade in Nepal. Proceeding of a national workshop; 1998 Aug. 25-28, Dhulikhel, Nepal. Bangkok (Thailand): Food and Agriculture Organization (FAO). Regional office for Asia and the Pacific. 15-21 p.

Shrestha, R. 1997. Ecological study of natural and degraded forest in Chitrepani, Makwanpur district. Nepal. M.Sc. thesis. Central Department of Botany, Tribhuvan University, Kathmandu, Nepal. 113 p.

Sigdel, E.R. 2004. Community forestry for biodiversity conservation and poverty alleviation, community forest bulletin no. 11, Kathmandu: Department of Forest, Community Forest Division, GoN, Nepal. 
Annex-6: Density (D, pl/m²), Relative Density (RD, \%), Frequency (F, \%), Relative Frequency (RF, \%), Coverage (C, \%), Relative Coverage (RC, \%) and Importance Value Index (IVI) of herb layer at SW slope

\begin{tabular}{|c|c|c|c|c|c|c|c|c|}
\hline SN & Name of the species & $\mathrm{D}\left(\mathrm{pl} / \mathrm{m}^{2}\right)$ & $\begin{array}{l}\text { RD } \\
(\%)\end{array}$ & $\begin{array}{c}F \\
(\%)\end{array}$ & $\begin{array}{l}\text { RF } \\
(\%)\end{array}$ & $\begin{array}{c}C \\
(\%)\end{array}$ & $\begin{array}{l}\mathrm{RC} \\
(\%)\end{array}$ & IVI \\
\hline \multicolumn{9}{|c|}{ Herbs } \\
\hline 1 & Carex cruciata & 2.34 & 21.72 & 47.91 & 13.00 & 5.39 & 11.53 & 46.26 \\
\hline 2 & Cymbopogon pendulus & 1.13 & 10.50 & 33.33 & 9.04 & 9.44 & 20.20 & 39.75 \\
\hline 3 & Capillipediuna assimilis & 1 & 9.28 & 16.66 & 4.52 & 4.02 & 8.60 & 23.40 \\
\hline 4 & Eulaliopsis binnata & 0.42 & 3.93 & 19.44 & 5.27 & 4.61 & 9.86 & 19.07 \\
\hline 5 & Curculigo orchioides & 0.52 & 4.83 & 27.08 & 7.34 & 2.37 & 5.07 & 17.25 \\
\hline 6 & Eranthemum cilatum & 0.49 & 4.57 & 15.27 & 4.14 & 2.32 & 4.96 & 13.68 \\
\hline 7 & Rungia parviflora & 0.17 & 1.69 & 5.55 & 1.50 & 0.69 & 1.47 & 4.59 \\
\hline 8 & Eragrostis tenella & 0.21 & 1.99 & 6.94 & 1.88 & 0.17 & 0.36 & 4.24 \\
\hline 9 & Imperata cylindrica & 0.18 & 1.67 & 4.16 & 1.12 & 0.53 & 1.13 & 3.93 \\
\hline 10 & Curcuma aromatica & 0.07 & 1.70 & 6.94 & 1.88 & 0.62 & 1.32 & 3.91 \\
\hline 11 & Arundinella nepalensis & 0.09 & 0.83 & 6.25 & 1.69 & 0.50 & 1.07 & 3.40 \\
\hline 12 & Chrysopogon acciculatus & 0.14 & 1.35 & 2.77 & 0.75 & 0.24 & 0.51 & 2.61 \\
\hline 13 & Adiantum philipense & 0.13 & 1.22 & 4.16 & 1.12 & 0.10 & 0.21 & 2.56 \\
\hline 14 & Cheilanthus bicolor & 0.14 & 1.35 & 2.77 & 0.75 & 0.15 & 0.32 & 2.42 \\
\hline 15 & Globba racemosa & 0.06 & 0.64 & 4.16 & 1.12 & 0.27 & 0.57 & 2.34 \\
\hline 16 & Heteropogon contortus & 0.08 & 0.77 & 2.77 & 0.75 & 0.34 & 0.72 & 2.25 \\
\hline 17 & Geniasporum coloratum & 0.05 & 0.51 & 3.47 & 0.94 & .34 & 0.72 & 2.18 \\
\hline 18 & Colocassia fallax & 0.04 & 0.45 & 4.16 & 1.12 & 0.10 & 0.21 & 1.79 \\
\hline 19 & Dioscorea hispida & 0.04 & 0.38 & 4.16 & 1.12 & 0.12 & 0.25 & 1.77 \\
\hline 20 & Dioscorea bulbifera & 0.07 & 0.70 & 2.77 & 0.75 & 0.06 & 0.12 & 1.58 \\
\hline 21 & Phyllanthus amarus & 0.05 & 0.51 & 2.08 & 0.56 & 0.22 & 0.47 & 1.54 \\
\hline 22 & Sida cordifolia & 0.04 & 0.45 & 2.08 & 0.56 & 0.05 & 0.10 & 1.12 \\
\hline 23 & Oxalis corniculata & 0.02 & 0.25 & 1.38 & 0.37 & 0.20 & 0.42 & 1.05 \\
\hline 24 & Leea macrophylla & 0.04 & 0.45 & 4.86 & 0.13 & 0.10 & 0.21 & 0.80 \\
\hline 25 & Ageratum conyzoides & 0.02 & 0.25 & 1.38 & 0.37 & 0.03 & 0.06 & 0.69 \\
\hline 26 & Chlorophytum nepalense & 0.01 & 0.12 & 1.38 & 0.37 & 0.03 & 0.06 & 0.56 \\
\hline 27 & Lygodium flexuosum & 0.01 & 0.12 & 1.38 & 0.37 & 0.03 & 0.06 & 0.56 \\
\hline 28 & Commelina erecta & 0.02 & 0.25 & 1.38 & 0.37 & 0.10 & 0.21 & 0.56 \\
\hline 29 & Cassia tora & 0.01 & 0.12 & 0.69 & 0.18 & 0.10 & 0.21 & 0.52 \\
\hline 30 & Knoxia roxburghii & 0.02 & 0.25 & 0.69 & 0.18 & 0.10 & 0.21 & 0.36 \\
\hline 31 & Dumosia villosa & 0.006 & 0.06 & 0.69 & 0.18 & 0.01 & 0.02 & 0.27 \\
\hline 32 & Scoparia dulcis & 0.006 & 0.06 & 0.69 & 0.18 & 0.01 & 0.02 & 0.27 \\
\hline \multicolumn{9}{|c|}{ Shrubs Seedling } \\
\hline 33 & Bauhinia vahlii & 0.11 & 1.03 & 9.72 & 2.63 & 0.55 & 1.17 & 4.84 \\
\hline 34 & Xeromphis spinosa & 0.09 & 0.83 & 7.6 & 2.06 & 0.36 & 0.77 & 3.67 \\
\hline 35 & Millettia extensa & 0.03 & 0.32 & 3.47 & 0.94 & 0.26 & 0.55 & 1.81 \\
\hline \multicolumn{9}{|c|}{ Trees Seedling } \\
\hline 36 & Shorea robusta & 2.47 & 23.01 & 86.80 & 23.55 & 10.65 & 22.79 & 69.36 \\
\hline 37 & Terminalia alata & 2.29 & 2.12 & 13.88 & 3.76 & 0.83 & 1.77 & 7.66 \\
\hline 38 & Semecarpus anacardium & 0.03 & 0.32 & 3.47 & 0.94 & 0.34 & 0.72 & 1.99 \\
\hline 39 & Schleichera oleosa & 0.02 & 0.25 & 2.08 & 0.56 & 0.22 & 0.47 & 1.39 \\
\hline 40 & Buchanania latifolia & 0.02 & 0.19 & 2.08 & 0.56 & 0.22 & 0.47 & 1.22 \\
\hline 41 & Holarhena pubscens & 0.01 & 0.12 & 1.38 & 0.37 & 0.03 & 0.06 & 0.56 \\
\hline \multicolumn{2}{|r|}{ Total } & 10.77 & 100 & 368.5 & 99.98 & 46.72 & 100 & 299.98 \\
\hline
\end{tabular}

Simpson, E.H. 1949. Measurement of diversity. Nature 163: 688.

Stainton, A. 1997.Flowers of the Himalaya: A supplement. New Delhi (India): Oxford University Press.72p+128 plates

Sundriyal, R.C. and E. Sharma. 1996. Anthropogenic Pressure on tree structure and biomass in the temperate forest of Mamlay Watershed in Sikkim. Forest Ecology and Management 81: 113-123.

Vetaas, O.R. 2000. The effect of environmental factors on the regeneration of Quercus semecarpifolia Sm. in central Himalaya,
Nepal. Plant Ecology 146: 137-144.

West, D.C., H.H. Shugart and J.W. Ranney. 1981. Population structure of forests over a large area. Forest Science 27: 701-710.

Whittaker, R.H. 1972. Evolution and Measurement of species diversity. Taxon. 21:231-251.

Zobel, D.B., P.K Jha, M.J. Behan and U.K.R. Yadav.1987. APractical Manual for Ecology, Ratna Book Distributors, Kathmandu, Nepal. 150 p. 